\title{
The Influence of Attitude, Subjective Norms, Perception of Self-Control And Entrepreneurship Education on Entrepreneurial Intentions
}

\author{
Shandy Aditya, BIB., MPBS \\ Fakultas Ekonomi Universitas Negeri Jakarta \\ E-mail : shandy@unj.ac.id
}

\begin{abstract}
Over the years, the field of entrepreneurship studies has become important in the world of education. The importance of entrepreneurship can support the view that entrepreneurship has become a major factor in the progress and expansion of the social economy, because it offers more job opportunities, as well as the impact on national growth and income distribution in a country. Many studies have shown the interaction between entrepreneurship education and entrepreneurial intentions. The aim of this study was to empirically examine factors such as personal attitudes, subjective norms, perceptions of self-control and entrepreneurial education that stimulate entrepreneurial intentions during higher education programs using data collected on campus. This research examines attitudes, norms, selfcontrol, and entrepreneurship education on entrepreneurial intentions. The research test used multiple linear regression analysis techniques with the help of the SPSS 23 program. Where the number of respondents in this study were 95 students of the Jakarta State University Management Study Program. Based on the results of the study, it can be seen that the research results show that the variable personal attitude affects entrepreneurial intention, self-control variable affects entrepreneurial intention, and the entrepreneurship education variable does not influence entrepreneurial intention.
\end{abstract}

\section{Keywords: Entrepreneurial Intentions, Subjective Norms, Entrepreneurship Ed- ucation, Attitude}

Received: 23 October 2020 ;

Accepted: 3 November 2020 ;

Publish; December 2020

\section{How to Cite:}

Aditya, S. (2020). The Influence of Attitude, Subjective Norms, Perception of SelfControl And Entrepreneurship Education on Entrepreneurial Intentions. Journal of Business and Behavioural Entrepreneurship, 4(2), 66-83. https://doi.org/10.21009/ JOBBE.004.2.06 


\section{INTRODUCTION}

Over the years, the field of entrepreneurship studies has become important in the world of education (Abdul, Salim, \& Kamarudin, 2012). The importance of entrepreneurship can be attributed to the view that entrepreneurship has been considered a major factor in social economic progress and expansion, because it offers more job opportunities, as well as the impact on national growth and income distribution in a country (Ali, Topping, \& Tariq, 2010). Akpan, \& Etor, (2013) describe entrepreneurs as humans who are able to do something different and recognize opportunities, which other people generally do not. Entrepreneurial activities are directed towards the development and implementation of business ideas by himself or what is called entrepreneurial intention (Gerba, 2012). Entrepreneurial intentions and activities offer opportunities for someone to achieve financial freedom, to have the authority and ability to make decisions. Besides that, it also has economic benefits, namely by helping in job creation, job opportunities, welfare and economic equality (Kurniawan, 2013).

One of the challenging problems facing developing countries is the high rate of youth unemployment. This problem makes the work environment very competitive because the availability of job vacancies is limited (Keat, Selvarajah \& Meyer, 2011). The open unemployment rate (TPT) in Indonesia reached 7 million people in August 2018, or 5.34 percent of the workforce. Compared to the same period last year, there was a decrease in the unemployment rate of 40,000 people (Kompas, 2018). The number of workforce itself reached 131.01 million people in August 2018, an increase of 2.95 million people compared to August 2017. While the working population was 124.01 million people, an increase of 2.99 million people compared to August 2017. When viewed more deeply, according to province, a number of provinces recorded an increase in the percentage of TPT, including DKI Jakarta. The unemployment rate in Jakarta was recorded to have increased from 290,120 in February 2018 to 314,840 people in August 2018 (BPS, 2019). In addition to the number of unemployed, BPS DKI noted, the open unemployment rate increased from 5.34 percent in February 2018 to 6.24 percent in August 2018. The open unemployment rate (TPT) is the percentage of the total unemployed to the total workforce. TPT is used to measure the level of labor supply that is not absorbed by the labor market.

Entrepreneurship is seen as a catalyst for economic growth and the State uses it as a strategy to reduce unemployment among youth. Most governments have made countless efforts to increase entrepreneurial activities (Akhmad, 2016). The Indonesian government has provided increased support for small businesses and entrepreneurs, with initiatives such as tax incentives and training support. Activities that have been carried out in introducing entrepreneurship among youth, for example, through entrepreneurship courses, entrepreneurial student programs, business competitions involving the role of successful small and medium enterprises (UKM) including training and internships as vital elements for the development of entrepreneurial skills (Chinamasa, 2014). Empirically Bae, Qian, Miao, \& Fiet, (2014) have conducted research that entrepreneurship education is treated as a broader concept than simple courses, as long as it includes entrepreneurial needs. In his research it was suggested that an effective program should consist of four components: (1) a taught component, with one or more modules; (2) business planning components, which can include competition and business plan suggestions for developing specific business ideas; (3) components of practice, which can include field activities; and (4) a university support component, which could include market research resources, meeting rooms, technology suites, and even startup funding for student business teams. Entrepreneurs are generally characterized

The Influence of Attitude, Subjective Norms, Perception of Self-Control And Entrepreneurship Education on Entrepreneurial Intentions. 
as individuals with a set of instincts, mindsets, inspiration, or visions who have the strength, will, and abilities needed to conceptualize ideas and to implement business plans and see change as an opportunity to create value from a business activity (Ariyani, 2016 ). For a long time, educators and professionals have been under the shadow that entrepreneurs are born, not formed. Subsequent studies claim that entrepreneurship can be taught (Akhmad, 2016; Astuti, R.D., \& Martdianty, 2012; Bae, Qian, Miao, \& Fiet, 2014)

Many studies have shown the interaction between entrepreneurship education and entrepreneurial intentions (Gerba et al., 2012; Kurniawan, 2013; Hassan and Wafa, 2012; Noel, 2001; Paco et al. 2012; Widawati, 2012; Schlaegel and Koenig, 2014). The purpose of this study was to empirically examine the factors that stimulate entrepreneurial intentions during higher education programs using data collected on campus. In this study it was investigated whether entrepreneurial intentions could be influenced by various types of factors such as entrepreneurship education, entrepreneurial attitudes, subjective norms, and behavior. Based on the above background, the writer takes the title the influence of personal attitudes, subjective norms, perceptions of selfcontrol and entrepreneurship education on entrepreneurial intentions.

Based on the background problem above, this study has objectives, including: 1 . To test the effect of attitudes on entrepreneurial intentions 2. Test the influence of norms on entrepreneurial intentions. 3 . Testing the effect of perceived self-control on entrepreneurial intentions. 4. Testing the effect of entrepreneurship education on entrepreneurial intentions.

\section{LITERATURE REVIEW}

Entrepreneurship is a value creation process that requires time and effort and with Entrepreneurship Education and potential income to be achieved through innovation in fulfilling needs and wants. So that it takes confidence to be able to create something new by utilizing all the available resources (Sukmaningrum and Rahardjo 2017). Adhitama (2014) describes the definition of entrepreneurship as a role model (entrepreneur), and strong-willed (effort). So an entrepreneur is someone who has determination or willpower and can be an example in life. It takes seriousness and exemplary role in becoming a successful entrepreneur (Adhi et al., 2017).

Intention is one of the strength factors of an entrepreneurial individual. Entrepreneurial intention is someone's desire to take an opportunity, opportunity or run a business by creating new products or services. Based on Rasli et al. (2014) stated that entrepreneurial intention is a desire that encourages someone to run a business. Entrepreneurial intention refers to the readiness shown to engage in certain behaviors in this case entrepreneurship. Rahardjo and Sukmaningrum (2017) explain that entrepreneurial intention is an individual's determination to run a business with that person's goals. According to Nur (2017), entrepreneurial intention is a courageous desire to solve life's problems and fulfill needs, create or advance their business with their strengths. Entrepreneurial intention is defined as the enthusiasm of people to be involved in entrepreneurship, to start a business or to participate in and complete an entrepreneurial activity (Engle et al., 2010).

Ajzen (1991) in Potishuk (2017) explains that intention can basically be used to explain motivational factors that can influence decision making or behavior. In psychology, the theory of planned behavior (abbreviated as TPB) is a theory that connects a person's beliefs and behavior. This theory states that intention towards behavior, sub-

The Influence of Attitude, Subjective Norms, Perception of Self-Control And Entrepreneurship Education on Entrepreneurial Intentions. 
jective norms, and perceived behavioral control together form the intention and behavior of individual behavior. This concept was proposed by Icek Ajzen to increase the predictive power of the theory of reasoned action by incorporating perceived behavioral control. It has been applied to the study of the relationship between beliefs, attitudes, behavioral intentions and behaviors in areas such as advertising, public relations, advertising campaigns, health, sports management and sustainability.

Attitude or Personal attitude (PA) is a personal position or mindset on a particular problem. In this proper framework, it refers to attitudes toward enterprise creation. Attitudes show individual beliefs about being entrepreneurial (Liñán \& Chen, 2009). Attitude refers to an evaluation of a person (positive or negative) or an assessment of one's behavior (Ajzen, 1991). Before forming intentions, people seem to make judgments for or against the behavior. TPB argues that attitudes are determined by a set of behavioral beliefs that link behavior with various outcomes and other attributes. Based on the evaluation of attitudes or beliefs, a person gets an attitude both positively and negatively. In this way, the attitudes that shape behavior (to start a business) when it is perceived as having encourage activities that seek the desired benefits or consequences for them. Unintended consequences result from negative attitudes toward behavior. A positive attitude towards entrepreneurship is considered attractive and beneficial for individuals, it will lead to better entrepreneurial intentions.

Subjective norms refer to the extent to which a relevant person or individual supports or does not support the performance of a particular behavior. In research, subjective norms can be measured by asking respondents to what extent entrepreneurs think family members, friends, or colleagues will support and be involved in entrepreneurial activities (Liñán \& Chen, 2009; Ajzen, 2001). It can be said that subjective norms are subjective perceptions of individuals (Fishbein \& Ajzen, 1975). According to Wedayanti and Giantari, (2016), subjective norms are the perceptions of people who are considered important in influencing actions or behavior, as well as the motivation related to taking actions that are considered important. Subjective norms are related to a person's social beliefs about what the people around him think and the motivation to follow these thoughts (Maulana, 2009).

Perceived behavioral control (PBC) is a person's perception of the ease or difficulty of carrying out tasks. $\mathrm{PBC}$ is a significant actor in the theory of planned behavior. Atkinson's (1964) theory of achievement motivation contains several elements of the perception of perceived self-control. It is described as the perceived probability of successfully performing a particular task. The theory of planned behavior is distinguished from the previous theory of reasoned action by Ajzen (1991) in the fact that it introduced $\mathrm{PBC}$ as previously described. The theory of planned behavior proposes that PBC, along with behavioral intention, may be a good predictor of individual achievement in a particular area. The majority of work done in the field of perceived selfcontrol is done on the basis of belief (Bolton \& Lane, 2012; Gerba, 2012; Rahmi, 2014). Beliefs about self-efficacy mostly have an impact on the choice of task or behavior to be performed, as well as the stability of a person's thoughts and emotions (Bandura, 1981). Ajzen distinguishes perceptions of self-control from locus of control introduced by Rucker (2011). The locus of control does not change over time, but remains relatively stable, whereas perceived behavioral control (perception of selfcontrol) may change over time. Locus of control states that a person's success depends on the effort made (Rucker, 2011).

Entrepreneurship education is defined as courses and courses that are part of the scope of the curriculum that offers students entrepreneurial skills, expertise and understanding, so that they can follow the entrepreneurial pathway as their profession

The Influence of Attitude, Subjective Norms, Perception of Self-Control And Entrepreneurship Education on Entrepreneurial Intentions. 
(Akhmad, 2016; Astuti, RD, \& Martdianty, 2012; Bae, Qian, Miao, \& Fiet, 2014). According to Gibson (2011), entrepreneurship education is an ongoing procedure that is taken to simplify the development of the acquaintances and skills needed to start a business. Gibson et al. (2011) stated that the main objective of entrepreneurship education is to develop and nurture skilled future entrepreneurs to start and maintain successful businesses, regardless of their educational background. According to Gerba (2012) entrepreneurship education is the educational activity of a person in increasing knowledge about entrepreneurship. Learning activities are not only about marketing or sales that seem to educate you to become a trader, but are able to create added value from related products or services (Nurseto, 2010). In entrepreneurship education, it is taught how to see opportunities and Entrepreneurship Education in facing the business world. According to Kurniawan (2013), entrepreneurship education is a discipline that studies values, skills, and behavior in facing the business world.

\section{RESEARCH METHODS}

The object of this research is the entrepreneurial interest of the Management Study Program students at State Universities (PTN) in the Jakarta area. This research was conducted during June - September 2019. Data was obtained by distributing questionnaires to the Jakarta State University (UNJ).

\section{Population}

According to Sugiyono (2014), population is a generalization area consisting of objects / subjects that have certain qualities and characteristics that are determined by researchers to be studied and then draw conclusions. The population in this study were active students at the Faculty of Economics, Jakarta State University, especially students from the Management study program and those who had taken entrepreneurship courses.

\section{Sample}

The sampling method in this research is Convenient Sampling. Convenient Sampling is the determination of samples based on chance, namely members of the population that the researcher meets and is willing to become respondents to be sampled (Iman, 2017). The data used in this study include primary data. Primary data collection by researchers using a questionnaire method. This questionnaire method is in the form of giving written questions and through a website-based questionnaire that is distributed online using google form to active management students of the Faculty of Economics, State University of Jakarta and who have taken entrepreneurship courses. Before filling out the questionnaire, the respondent will be explained by the researcher about the purpose of this study and explain to fill in the questionnaire honestly, so that it is expected to get accurate results.

\section{Data Analysis}

The data in the study were tested using Multiple Linear Regression Analysis. The multiple linear regression model in this study uses the classical assumption test, namely: normality test, multicolinearity test, test and heteroscedasticity.

The Influence of Attitude, Subjective Norms, Perception of Self-Control And Entrepreneurship Education on Entrepreneurial Intentions. 


\section{RESULT AND DISCUSSION}

\section{Validity test}

Where the validity test uses the Pearson formula, with 20 respondents to the trial. The basis for making a decision to state whether or not each item of the statement is valid is to compare the results (r) count with (r) table. (r) the table used in this study is 0.423 . Based on the results of the validity test in this study, it is known that for the statement on the Entrepreneurial Intention variable (Y) there is one item of statement, namely the statement with code NB4 which is declared invalid because there is a (r) count below 0.423 , so it is declared invalid and the statement cannot enrolled in the research questionnaire. In addition, knowledge of Attitudes (X1), Subjective Norms (X2), Perceptions of Self-Control (X3), and Entrepreneurship Education (X4), there are no statement items whose value (r) is calculated below 0.423 . So that all statement items on the four variables are declared valid and usable.

\section{Reliability Test}

Reliability measurement is done by using Cronbach Alpha statistical test. A variable is said to be reliable if it provides a Cronbach Alpha value $=0.60$ (Imam, 2011: 48). Based on the results of the reliability test in this study. The entrepreneurial intention variable from the seven statement items got the reliability results $(0.682)$, the Personal Attitude variable from the five statement items got the reliability results $(0.709)$ then, the Subjective Norm variable from the five statement items got the reliability results (0.866). In addition, the Perception of Self-Control variable from the five statement items got the reliability result (0.678), and the Entrepreneurship Education variable from the five statement items got the reliability result $(0.898)$. It can be concluded that each variable is declared reliable.

\section{Classic assumption test}

In this study, before testing the hypothesis on the data that has been obtained, the classical assumption is first tested. Where the classical assumption test is carried out three tests, namely the normality test, multicollinearity test, and heteroscedasticity test.

\section{Normality test}

Normality test uses graph analysis or P-Plot and Kolmogorov Smirnov test. Where the decision making regarding the resulting P-Plot results is if the data spreads around the diagonal line and follows the direction of the diagonal line or the histogram graph shows that the distribution pattern is normal, then the data is normally distributed. If the data spreads far from the diagonal line and or does not follow the direction of the diagonal line or the histogram graph does not show a normal distribution pattern, then the data is not normally distributed. Following are the results of the P-Plot normality test.

The Influence of Attitude, Subjective Norms, Perception of Self-Control And Entrepreneurship Education on Entrepreneurial Intentions. 


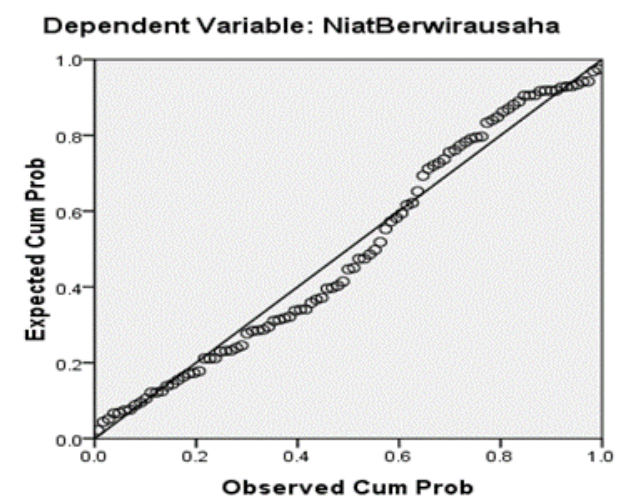

Source: Data processed by SPSS 23, 2019

To be more convincing, the researchers used the Kolmogorov-Smirnov test by making the hypothesis Ho is normally distributed data while $\mathrm{Ha}$ is data that is not normally distributed (Ghozali, 2016: 158). If the results of the Kolmogorov-Smirnov test show $>0.05$ (significance level), then Ho is accepted so that the data is normally distributed. If the results are $<0.05$, then Ho is rejected so that the data are not normally distributed. If the data is not normally distributed or the number of samples is too small, non-parametric statistics will be used.

Table 1. Normality Test Result

\begin{tabular}{|c|c|c|}
\hline & Unstandardized Residual \\
\hline \multicolumn{2}{|l|}{$\mathrm{N}$} & 95 \\
\hline \multirow{2}{*}{$\begin{array}{l}\text { Normal Pa- } \\
\text { rameters }^{\mathrm{a}, \mathrm{b}}\end{array}$} & Mean & .0000000 \\
\hline & $\begin{array}{l}\text { Std. Devia- } \\
\text { tion }\end{array}$ & 281.252 .367 \\
\hline \multirow{3}{*}{$\begin{array}{l}\text { Most Extreme } \\
\text { Differences }\end{array}$} & Absolute & .070 \\
\hline & Positive & .059 \\
\hline & Negative & -.070 \\
\hline \multicolumn{2}{|l|}{ Test Statistic } & .070 \\
\hline \multicolumn{2}{|c|}{ Asymp. Sig. (2-tailed) } & $.200^{\mathrm{c}, \mathrm{d}}$ \\
\hline
\end{tabular}

Test distribution is Normal.

Source: Data processed by SPSS 23, 2019

The Influence of Attitude, Subjective Norms, Perception of Self-Control And Entrepreneurship Education on Entrepreneurial Intentions. 
In this study, the results of the normality test with Kolmogorov Smirnov showed that the significance of the data was 0.2 where the data had a significance value of $>$ 0.05 . So that the distribution of data in this study can be declared normal.

\section{Multicollinearity Test}

The multicollinearity test was conducted to determine whether there was a correlation problem between variables. Based on the multicollinearity test conducted in Table IV.10, it is known that each independent variable gets a VIF result of (1.298) for Personal Attitudes, (1.615) for Subjective Norms (1.587) for Perceptions of SelfControl, and (1.268) for Entrepreneurship Education where the results VIF is in the range of number one and not more than number 10 . This shows that there is no multicollinearity problem in each of the independent variables in this study.

Table 2. Multicollinearity Test Result

\begin{tabular}{|c|c|c|c|c|c|c|c|c|}
\hline & \multirow{2}{*}{ Model } & \multicolumn{2}{|c|}{$\begin{array}{c}\text { Unstandardized } \\
\text { Coefficients }\end{array}$} & \multirow{2}{*}{$\begin{array}{c}\text { Standardized } \\
\text { Coefficients } \\
\text { Beta }\end{array}$} & \multirow{2}{*}{$\mathrm{T}$} & \multirow{2}{*}{ Sig. } & \multicolumn{2}{|c|}{$\begin{array}{c}\text { Collinearity Sta- } \\
\text { tistics }\end{array}$} \\
\hline & & B & Std. Error & & & & Tolerance & VIF \\
\hline \multirow{5}{*}{1} & (Constant) & 8.442 & 2.419 & & 3.490 & $\begin{array}{r}.00 \\
1\end{array}$ & & \\
\hline & Personal Attitude & .282 & .098 & .258 & 2.881 & $\begin{array}{r}.00 \\
5\end{array}$ & .771 & $\begin{array}{r}1.29 \\
8\end{array}$ \\
\hline & Subjective Norms & .372 & .127 & .293 & 2.932 & $\begin{array}{r}.00 \\
4\end{array}$ & .619 & $\begin{array}{r}1.61 \\
5\end{array}$ \\
\hline & $\begin{array}{l}\text { Perceptions of Self- } \\
\text { Control }\end{array}$ & .300 & .120 & .248 & 2.506 & $\begin{array}{r}.01 \\
4\end{array}$ & .630 & $\begin{array}{r}1.58 \\
7\end{array}$ \\
\hline & $\begin{array}{l}\text { Entrepreneurship } \\
\text { Education }\end{array}$ & .054 & .083 & .058 & .656 & $\begin{array}{r}.51 \\
3\end{array}$ & .788 & $\begin{array}{r}1.26 \\
8\end{array}$ \\
\hline
\end{tabular}

Source: Data processed by SPSS 23, 2019

\section{Heteroscedasticity Test}

The heteroscedasticity test was carried out in this study by looking at the results of the Glejser test. Where the decision making for the Glejser test is done by comparing the significance level of the test results with an alpha value of 0.05 . If the results show a siginfikansi above 0.05 then there is no heteroscedasticity problem.

Table 3. Heteroscedasticity Test Result

\begin{tabular}{|c|c|c|c|c|c|c|}
\hline & \multirow{2}{*}{ Model } & \multicolumn{2}{|c|}{$\begin{array}{c}\text { Unstandardized Co- } \\
\text { efficients }\end{array}$} & \multirow{2}{*}{$\begin{array}{c}\text { Standardized } \\
\text { Coefficients }\end{array}$} & \multirow{2}{*}{$\mathrm{t}$} & \multirow{2}{*}{ Sig. } \\
\hline & & B & Std. Error & & & \\
\hline \multirow{5}{*}{1} & (Constant) & 3.772 & 1.561 & & 2.417 & .018 \\
\hline & Personal Attitude & -.039 & .063 & -.073 & -.613 & .542 \\
\hline & Subjective Norms & -.067 & .082 & -.109 & -.821 & .414 \\
\hline & Perceptions of Self-Control & .011 & .077 & .019 & .142 & .888 \\
\hline & Entrepreneurship Education & .019 & .053 & .041 & .349 & .728 \\
\hline
\end{tabular}

Dependent Variable: Abs_RES

The Influence of Attitude, Subjective Norms, Perception of Self-Control And Entrepreneurship Education on Entrepreneurial Intentions. 
The Personal Attitude variable has a significance value (0.542), the Subjective Norm variable has a significance value $(0.414)$, the Perception Self-Control variable has a significance value (0.888), while the Entrepreneurship Education variable has a significance value (0.728). Based on the results of heteroscedasticity, the results of each independent variable show a significance above 0.05 . Where this shows the absence of heteroscedasticity problems in each of the independent variables in this study.

\section{Hypothesis test}

The hypothesis test conducted in this study consisted of three tests, namely the partial hypothesis test or T test, and the coefficient of determination test or R2. However, before testing the hypothesis, a multiple linear regression test is conducted first.

\section{Multiple linear regression}

Multiple linear regression in this study aims to determine the effect of the four independent variables, namely Personal Attitude (X1), Subjective Norms (X2), Perceptions of Self-Control (X3), and Entrepreneurship Education (X4).

Table 4. Multiple Linear Regression Result

\begin{tabular}{|c|c|c|c|c|c|c|}
\hline & \multirow{2}{*}{ Model } & \multicolumn{2}{|c|}{$\begin{array}{l}\text { Unstandardized Co- } \\
\text { efficients }\end{array}$} & \multirow{2}{*}{$\begin{array}{c}\text { Standardized } \\
\text { Coefficients }\end{array}$} & \multirow{2}{*}{$\mathrm{t}$} & \multirow[t]{2}{*}{ Sig. } \\
\hline & & B & Std. Error & & & \\
\hline \multirow{5}{*}{1} & (Constant) & 8.442 & 2.419 & & 3.490 & .001 \\
\hline & Personal Attitude & .282 & .098 & .258 & 2.881 & .005 \\
\hline & Subjective Norms & .372 & .127 & .293 & 2.932 & .004 \\
\hline & Perceptions of Self-Control & .300 & .120 & .248 & 2.506 & .014 \\
\hline & Entrepreneurship Education & .322 & .123 & .238 & 2.405 & .013 \\
\hline
\end{tabular}

Based on the table above, it can be seen that the regression equation for this research model is as follows:

$$
\mathrm{Y}=8,442+0,282 \mathrm{SP}+0,372 \mathrm{NS}+0,300 \mathrm{PPD}+0,322 \mathrm{PK}+\mathrm{e}
$$

$\mathrm{Y}=$ Entrepreneurial Intentions

$\mathrm{X} 1=$ Personal Attitude

$\mathrm{X} 2=$ Subjective Norms

X3 = Perceptions of Self-Control

$\mathrm{X} 4=$ Entrepreneurship Education

$\beta=$ Koefisien regresi

$\mathrm{e}=$ Error

Where the regression results above can be explained as follows:

1. Personal Attitude Variable (X1) of 0.282. This shows that each addition of one Personal Attitude variable will increase Entrepreneurial Intention by 0.282 .

2. The regression coefficient for the Subjective Norm variable is 0.372. So it can be interpreted that each addition of one Subjective Norm will increase Entrepreneurial Intention by 0.372 .

3. The regression coefficient for the Perceptions of Self-Control variable gets a result of 0.300 , which means that for every addition of one perception, Self-Control will

The Influence of Attitude, Subjective Norms, Perception of Self-Control And Entrepreneurship Education on Entrepreneurial Intentions. 
increase Entrepreneurial Intention by 0.300 .

4. The regression coefficient for the Entrepreneurship Education variable shows the number 0.322. So it can be interpreted that each addition of Entrepreneurship Education as much as one will increase Entrepreneurial Intention by 0.322 .

\section{T test}

The $t$ test or partial test is conducted to determine the effect of independent variables on the dependent variable separately. The decision making for the test is done by comparing the results of the statistical test with the $t$ table and by looking at the significance of each variable. The table value used is 1.98667 , where the results are obtained from the 90 degrees of freedom in alpha for the two-sided test of 0.05 . The determination of 90 degrees of freedom is from the number of samples, namely 95 minus the number of variables, namely 5 . If the statistical test result is greater than 1.98667 or less than -1.98667 with a significance below 0.05 , the variable is declared influential. Where based on the results of the coefficient on the SPSS output which can be seen in table IV.13 shows the following results.

The first hypothesis in this study is about the influence of personal attitudes on entrepreneurial intentions. The Personal Attitude variable (X1) obtained the T statistical test result of 2.881, which is greater than the table value of 1.98667 . With a significance of 0.005 less than 0.05 . Based on this, it is known that the variable personal attitude has an effect on the entrepreneurial intention variable.

The second hypothesis in this study is about the influence of Subjective Norms on Entrepreneurial Intentions. The Subjective Norm variable (X2) obtained the t statistical test result of 2.932 greater than the table value of 1.98667 . With a significance level of 0.004 less than 0.05 . This shows that the Subjective Norm variable has a significant effect on Entrepreneurial Intentions.

The third hypothesis in this study is about the effect of Perceptions of SelfControl on Entrepreneurial Intention. Where the Perceived Self-Control variable (X3) gets the $t$ statistical test result of 2.506 which is greater than the table value of 1.98667 . With a significance value of 0.014 less than 0.05 . This shows that the variable Perception of Self-Control has a significant effect on Entrepreneurial Intention.

The fourth hypothesis in this study is about the effect of entrepreneurship education on entrepreneurial intentions. Where the Entrepreneurship Education variable (X4) gets the $t$ statistical test result 2.405 greater than the table value 1.98667 . With a significance of 0.013 greater than 0.05 . This shows that the entrepreneurship education variable has an effect on entrepreneurial intentions.

Table 5. T-Test Result

\begin{tabular}{|c|c|c|c|c|c|c|}
\hline & \multirow{2}{*}{ Model } & \multicolumn{2}{|c|}{$\begin{array}{l}\text { Unstandardized Co- } \\
\text { efficients }\end{array}$} & \multirow{2}{*}{$\begin{array}{c}\text { Standardized } \\
\text { Coefficients }\end{array}$} & \multirow[t]{2}{*}{$\mathrm{T}$} & \multirow[t]{2}{*}{ Sig. } \\
\hline & & B & Std. Error & & & \\
\hline \multirow{5}{*}{1} & (Constant) & 8.442 & 2.419 & & 3.490 & .001 \\
\hline & Personal Attitude & .282 & .098 & .258 & 2.881 & .005 \\
\hline & Subjective Norms & .372 & .127 & .293 & 2.932 & .004 \\
\hline & Perceptions of Self-Control & .300 & .120 & .248 & 2.506 & .014 \\
\hline & Entrepreneurship Education & .322 & .123 & .238 & 2.405 & .013 \\
\hline
\end{tabular}

Source: Data processed by SPSS 23, 2019

The Influence of Attitude, Subjective Norms, Perception of Self-Control And Entrepreneurship Education on Entrepreneurial Intentions. 


\section{Coefficient of Determination (R-square)}

The coefficient of determination shows how much the ability of the research model to describe the influence between the variables in the study. The results of the determination coefficient test in the SPSS program are shown in the output model summary in the following table.

Table 6. R-square Result

\begin{tabular}{|r|c|r|r|r|}
\hline Model & \multicolumn{1}{|c|}{$\mathrm{R}$} & R Square & Adjusted R Square & $\begin{array}{c}\text { Std. Error of } \\
\text { the Estimate }\end{array}$ \\
\hline 1 & $.667^{\mathrm{a}}$ & .445 & .420 & 2.874 \\
\hline
\end{tabular}

Source: Data from SPSS 23, 2019

Based on the results of the coefficient of determination, it is known that the Adjusted $\mathrm{R}$ Square results in 0.445 . Where this shows that the four independent variables are able to explain the entrepreneurial intention variable by $44.5 \%$. Meanwhile, the remaining $55.5 \%$ is explained by other variables not included in this study.

\section{Discussion}

\section{There is an influence of Personal Attitude on Entrepreneurial Intentions}

In the $\mathrm{H} 1$ test results in table IV.13, it can be seen that $\mathrm{H} 1$ is accepted, so it can be said that Personal Attitude has an effect on Entrepreneurial Intention. The results seen from this study are based on the percentage table of answers to the questionnaire in the appendix which states that personal attitudes affect entrepreneurial intentions. This shows that students have strong personal attitudes, beliefs and motivation in making decisions to become entrepreneurs.

The results of this study are in line with Listyawati's research (2017) which states that personal attitude has a significant effect on entrepreneurial intentions. These results are in line with research by Amran et al (2016), Sah (2013), Andika and Madjid (2012), Linan et al. (2011) Hein (2011), Wijaya (2008), Van Galderen et al. (2006) that personal attitudes have an influence on entrepreneurial intentions. Students who have a personal attitude will tend to make entrepreneurial decisions. The higher the attitudes and beliefs you have, the higher your interest in entrepreneurship will be.

\section{There is an influence of Subjective Norms on Entrepreneurial Intentions}

In the $\mathrm{H} 2$ test results in table IV.13 it can be seen that $\mathrm{H} 2$ is accepted so that it can be said that Subjective Norms have an effect on Entrepreneurial Intention. The results seen from this study are based on the percentage table of the questionnaire answers. The growth in the percentage of entrepreneurs has increased well, one of which is because the community supports entrepreneurial activities in their environment. This is driven by the development of technology or digital business that is increasingly advanced, making it easier to do business. The results of this study indicate that the support from the environment or norms prevailing in society for students to be entrepreneurial is proven to affect their entrepreneurial intentions. The results of this study are in line with Awang's research (2016) which states that the Subjective Norm variable has a significant effect on Entrepreneurial Intention. This result is not in line with re-

The Influence of Attitude, Subjective Norms, Perception of Self-Control And Entrepreneurship Education on Entrepreneurial Intentions. 
search conducted by Andika and Madjid (2012) which concluded that the subjective norm variable does not have a significant effect on interest in entrepreneurship. This may be due to the lack of support from parents in the environment for student interest in entrepreneurship.

\section{There is the influence of Perceptions of Self-Control on Entrepreneurial Intentions}

In the results of the $\mathrm{H} 3$ test in table IV.13, it can be seen that H3 is accepted so that it can be said that the Perception of Self-Control has an effect on Entrepreneurial Intention. The results seen from this study are based on the percentage table of the questionnaire answers. This shows that the easier the perception of self-control felt by students, it means that the general reality conditions that students have in making decisions to become entrepreneurs are easy. The results of this study are in line with Darmawan's (2016) research that the perception of self-control has an effect on entrepreneurial intentions. The same results in research conducted by Warmika (2016) stated that one of the factors that influenced students' entrepreneurial intentions was the Perception of Self-Control. The greater the perception of self-control that may be obtained, the greater the entrepreneurial intention of students in the capital market.

\section{There is an influence of Entrepreneurship Education on Entrepreneurial Intentions.}

In the results of the $\mathrm{H} 4$ test in table IV.13, it can be seen that H4 is accepted, so it can be said that Entrepreneurship Education has an effect on Entrepreneurial Intention. Before deciding to become an entrepreneur, students need to have knowledge about the business world that they will choose. So that the availability of adequate information makes it easier for students to practice. Thus, education regarding entrepreneurship is absolutely necessary for a prospective entrepreneur before entering the world of business. This adequate knowledge will form a person's ability to create value and profit and also be able to manage an existing entrepreneurship both small and large so as to reduce the impact of losses that will be experienced. For students, especially management study program students who have received courses on entrepreneurship material, of course this has become one of the capital of knowledge to be able to join the business world later. The results of this study are in line with research conducted by Rembulan (2017) that Entrepreneurship Education has a significant effect on Entrepreneurial Intention. And research conducted by Atmaja (2016) and Astiti (2015) which states that entrepreneurship education has a significant effect on entrepreneurial intentions.

The results of this study helped the university in strengthening TPB (theory planned behavior) at UNJ. Most of the factors in the TPB can be verified. The results directly verify that students who have received entrepreneurship courses have high intentions, attitudes, norms and perceptions of control that are also better. In terms of subjective norm variables, it shows that planned behavior in entrepreneurship has an impact on the mindset of parents and their social members. Perceptions of self-control show that students have a tendency to take risks and a proactive personality and are good predictors of entrepreneurial intentions. On the other hand, the four variables are direct determinants of entrepreneurial intentions. Therefore this study supports the preliminary findings of Luthje and Frank (2003) and Duijn (2009) in the Netherlands.

The Influence of Attitude, Subjective Norms, Perception of Self-Control And Entrepreneurship Education on Entrepreneurial Intentions. 
Personal attitudes, subjective norms and perceptions of self-control predict higher entrepreneurial intentions. Thus the students emphasized that the current situation between their parents and the social environment provided several alternatives that could realize their intentions for an entrepreneurial career. This finding supports Ajzen (1991) and Krueger et al. (2000). This study extends the analysis in the TPB model in which the influence effects of attitudes, perceptions of self-control and subjective norms are substantiated. This study proves that there will be more startups among university graduates in the country if they receive serious attention and are able to focus on their hopes and receive support from the university, family, friends and peers. In addition, it can also strengthen a proactive personality and a tendency to take risks in entrepreneurship in the future.

\section{CONCLUSION}

This research examines the effect of attitudes, norms, perceptions of self-control, and entrepreneurship education on entrepreneurial intentions. The research test used multiple linear regression analysis techniques with the help of the SPSS 23 program. Where the number of respondents in this study were 95 students of Management Study Program, State University of Jakarta. Based on the research results, it can be concluded that 1 . There is an effect of personal attitudes on entrepreneurial intentions. This can be interpreted, if personal attitudes increase, then the entrepreneurial intentions of UNJ Management Study Program students will increase. So, the first hypothesis is that there is an effect of personal attitudes on the entrepreneurial intention of UNJ Management Study Program students, accepted. 2. There is an influence of subjective norms on entrepreneurial intentions. This can be interpreted, if the subjective norms increase, then the entrepreneurial intention of UNJ Management Study Program students will increase. So, the second hypothesis is that there is an influence of subjective norms on the entrepreneurial intention of UNJ Management Study Program students, accepted. 3 . There is an effect of perceived self-control on entrepreneurial intentions. This can be interpreted, if the perception of self-control increases, the entrepreneurial intention of UNJ Management Study Program students will increase. So, the third hypothesis, there is an effect of perceived self-control on the entrepreneurial intentions of UNJ Management Study Program students, is accepted. 4. There is no influence of entrepreneurship education on entrepreneurial intentions. Where entrepreneurship education is used in determining student entrepreneurial intentions. So, the fourth hypothesis is that there is an effect of entrepreneurship education on the entrepreneurial intention of UNJ Management Study Program students in the capital market, accepted.

\section{Suggestion}

Based on this research, the suggestions for students are 1. Provide more understanding regarding the importance of entrepreneurship 2. Provide encouragement for students to dare to be directly involved in entrepreneurship by utilizing facilities and infrastructure such as entrepreneurship lab facilities available on campus 3. Providing understanding in considering perceptions of self-control and entrepreneurship education to start entrepreneurship. For Universities 1. Provide compulsory entrepreneurship courses so that students have a basic personal attitude to entrepreneurship 2. Empower as much as possible the facilities and infrastructure available on campus as a means of education, socialization, and the extent to which students can practice theories in lectures and support research activities 3. Cooperate with successful entrepreneurs to

The Influence of Attitude, Subjective Norms, Perception of Self-Control And Entrepreneurship Education on Entrepreneurial Intentions. 
provide capital market seminars and training for students. For further researchers: 1) It is recommended not to limit the research location to certain regional universities, in order to obtain more relevant results, 2) It is recommended to conduct research on entrepreneurial intentions not only for students but with various professional backgrounds in order to obtain more accurate results.

\section{REFERENCE}

Adhitama, P. P. (2014). Faktor-Faktor Yang Mempengaruhi Minat Berwirausaha (Studi Kasus Mahasiswa Fakultas Ekonomika Dan Bisnis Undip, Semarang).

Adi, F., Sumarwan, U., Fahmi, I., Adi, F., Sumarwan, U., \& Fahmi, I. (2017). Pengaruh Faktor Sikap, Norma Subjektif, Demografi, Sosioekonomi serta Literasi Keuangan Syariah dan Konvensional terhadap Minat Berwirausaha pada Mahasiswa. Jurnal AlMuzara'ah, 5(1), 1-20.

Abdul Kadir, M.B., Salim, M., \& Kamarudin, H. (2012). The Relationship Between Educational Support and Entrepreneurial Intentions in Malaysian Higher Learning Institution. International Conference on Education and Educational Psychology (ICEEPSY 2012). Procedia - Social and Behavioural Sciences, 69 21642173.

Agbim, K.C., Oriarewo, G.O., \& Owocho, M. (2013). Factors Influencing Entrepreneurial Intentions among Graduates of Nigerian Tertiary Institutions. International Journal of Business and Management Invention 2(4), 36-44.

Agbim, K.C., Oriarewo, G.O., \& Ijie, N. (2013). The relative importance of spirituality in entrepreneurship development among graduates of Nigerian tertiary institutions. International Journal of Business and Management Invention 2(4), 25-35.

Ajzen, I. (1985). From intentions to actions: A theory of planned behavior. In J. Kuhl \& J. Beckman (Eds.).

Ajzen, I. (1991). The Theory of Planned Behavior. Organizational Behavior and Human Decision Processes, 50(2), 179-211. https://doi.org/10.1016/0749-5978(91) 90020-T

Ajzen, I. (2001). Nature and Operation of Attitudes. Annual Review of Psychology, 52 (1), 27-58. https://doi.org/10.1146/annurev.psych.52.1.27

Ajzen, I., \& Fishbein, M. (1977). Attitude-behavior relations: A Theoretical Analysis and Review of Empirical Research. Psychological Bulletin, 84(5), 888-918. https://doi.org/10.1037/0033-2909.84.5.888

Ali, A., Topping, K.J., \& Tariq, R.H. (2010). Entrepreneurial attributes among postgraduate students of a Pakistani university. US-China Education Review, 7(5).

Akpan, C., \& Etor, C. (2013). University Lecturers' Perception of Entrepreneurship Education as an Empowerment Strategy for Graduate Self- Employment in South- South Nigeria. International Journal of Asian Social Science, 3(5), 11801195.

Akhmad Yafiz Syam, L. (2016). Minat Berwirausaha Mahasiswa yang Telah Menempuh Mata Kuliah Kewirausahaan, 6, 1-8. Amir, N. (2017). Faktor-faktor yang Mempengaruhi Intensi Berwirausaha pada Kalangan Mahasiswa. Organisasi Dan Manajemen, 1(1), 1-13.

Ariyani, L. (2016). Faktor-Faktor Yang Mempengaruhi Intensi Berwirausaha Pada Mahasiswa Program S1, 1(1), 1-13. https://doi.org/10.13140/

RG.2.2.12034.17602 
Astuti, R.D., \& Martdianty, F. (2012). Students' Perception and Intention toward Entrepreneurship: Development of Planned Behaviour Entrepreneurial Model on Six State Universities in Indonesia. 2nd Annual International Conference on Enterprise Marketing and Globalization (EMG 2012).

Bae, T. J., Qian, S., Miao, C., \& Fiet, J. O. (2014). The Relationship Between Entrepreneurship Education and Entrepreneurial Intentions: A Meta-Analytic Review. Entrepreneurship: Theory and Practice, 38(2), 217-254. https://doi.org/10.1111/ etap. 12095

Bandura, A. (1997). Self-efficacy: toward a unifying theory of behavioural change. Psychological Review, 84, 191-215. 7.

Baron, R. A. (2004). The cognitive perspective: a valuable tool for answering entrepreneurship's basic —whyll questions. Journal of Business Venturing, 19(2), 221239.

Beritasatu.com. (2018). Indonesia Berpotensi Jadi Negara Maju. http:// www.beritasatu.com/ekonomi/224807-pakar-dari-as-indonesia berpotensijadinegara-maju.html (diakses Juli 10, 2018)

Bird, B. (1988). Implementing entrepreneurial ideas: the case for intention. Academy of Management Review 13(3), 442-453.

Bolton, D. L., \& Lane, M. D. (2012). Individual entrepreneurial orientation: Development of a measurement instrument. Education \& Training, 54, 219-233.

Cruz, L.D., Suprapti, S., Yasa, K. (2015). Aplikasi Theory Of Planned Behavior Dalam Membangkitkan Niat Berwirausaha Bagi Mahasiswa Fakultas Ekonomi Unpaz, Dili Timor Leste. E-Jurnal Ekonomi dan Bisnis Universitas Udayana. Vol. 4 No. 12, pp. 895-920.

Engle, R.L., Dimitriadi, N., Gavidia, J.V., Schlaegel, C., Delanoe, S., Alvarado, I., He, X., Buame, S., \& Wolff, B. (2010). Entrepreneurial intent a twelve country evaluation of Ajzen's model of planned behaviour. International Journal of Entrepreneurial Behaviour \& Research, 16(1), 35-57.

Fretschner, M. \& Weber, S. (2013). Measuring and Understanding the Effects of Entrepreneurial Awarness Education. Journal of Small Business Management 51 (3): 410-428.

Gerba. D. T. (2012). Impact of entrepreneurship education on entrepreneurial intentions of business and engineering students in Ethiopia.African Journal of Economic and Management Studies.Vol. 3 No. 2.pp. 258-277.

Ghufron, M.N., dan Risnawita, S. (2009). Teori-Teori Psikologi. Jakarta: Gramedia

Iakovleva, T., Kolvereid, L., \& Stephan, U. (2011). Entrepreneurial intentions in developing and developed countries. Education \& Training, 53(5), 353-370. http:// dx.doi.org/10.1108/00400911111147686

Kurniawan, R. (2013). Pengaruh Penerapan Model Pembelajaran Teaching Factory Langkah (TF-6M) dan Prestasi Belajar kewirausahaan Terhadap Minat Wirausaha.Jurnal Pendidikan Teknologi Kejuruan.Vol. 10 No. 1.pp. 57-66.

Kautonen, T., Gelderen., M. V. \& Fink, M. (2015). Robustness of theory of planned behavior in predicting entrepreneurial intentions and actions. Entrepreneurship Theory \& Practice, 39(3), 655-674.

Liñán, F. (2008). Skill and value perceptions: how do they affect entrepreneurial intentions? International Entrepreneurship and Management Journal, 4(3), 257-272.

Liñán, F. \& Chen, Y. W. (2009). Development and cross-cultural application of a specific instrument to measure entrepreneurial intentions. Entrepreneurship Theory and Practice, 33(3), 593-617.

The Influence of Attitude, Subjective Norms, Perception of Self-Control And Entrepreneurship Education on Entrepreneurial Intentions. 
Adhitama, P. P. (2014). Faktor-Faktor Yang Mempengaruhi Minat Berwirausaha (Studi Kasus Mahasiswa Fakultas Ekonomika Dan Bisnis Undip , Semarang).

Adi, F., Sumarwan, U., Fahmi, I., Adi, F., Sumarwan, U., \& Fahmi, I. (2017). Pengaruh Faktor Sikap, Norma Subjektif, Demografi, Sosioekonomi serta Literasi Keuangan Syariah dan Konvensional terhadap Minat Berwirausaha pada Mahasiswa. Jurnal AlMuzara'ah, 5(1), 1-20.

Abdul Kadir, M.B., Salim, M., \& Kamarudin, H. (2012). The Relationship Between Educational Support and Entrepreneurial Intentions in Malaysian Higher Learning Institution. International Conference on Education and Educational Psychology (ICEEPSY 2012). Procedia - Social and Behavioural Sciences, 69 21642173.

Agbim, K.C., Oriarewo, G.O., \& Owocho, M. (2013). Factors Influencing Entrepreneurial Intentions among Graduates of Nigerian Tertiary Institutions. International Journal of Business and Management Invention 2(4), 36-44.

Agbim, K.C., Oriarewo, G.O., \& Ijie, N. (2013). The relative importance of spirituality in entrepreneurship development among graduates of Nigerian tertiary institutions. International Journal of Business and Management Invention 2(4), 25-35.

Ajzen, I. (1985). From intentions to actions: A theory of planned behavior. In J. Kuhl \& J. Beckman (Eds.).

Ajzen, I. (1991). The Theory of Planned Behavior. Organizational Behavior and $\mathrm{Hu}-$ man Decision Processes, 50(2), 179-211. https://doi.org/10.1016/0749-5978(91) 90020-T

Ajzen, I. (2001). Nature and Operation of Attitudes. Annual Review of Psychology, 52 (1), 27-58. https://doi.org/10.1146/annurev.psych.52.1.27

Ajzen, I., \& Fishbein, M. (1977). Attitude-behavior relations: A Theoretical Analysis and Review of Empirical Research. Psychological Bulletin, 84(5), 888-918. https://doi.org/10.1037/0033-2909.84.5.888

Ali, A., Topping, K.J., \& Tariq, R.H. (2010). Entrepreneurial attributes among postgraduate students of a Pakistani university. US-China Education Review, 7(5).

Akpan, C., \& Etor, C. (2013). University Lecturers' Perception of Entrepreneurship Education as an Empowerment Strategy for Graduate Self- Employment in South- South Nigeria. International Journal of Asian Social Science, 3(5), 11801195.

Akhmad Yafiz Syam, L. (2016). Minat Berwirausaha Mahasiswa yang Telah Menempuh Mata Kuliah Kewirausahaan, 6, 1-8. Amir, N. (2017). Faktor-faktor yang Mempengaruhi Intensi Berwirausaha pada Kalangan Mahasiswa. Organisasi Dan Manajemen, 1(1), 1-13.

Ariyani, L. (2016). Faktor-Faktor Yang Mempengaruhi Intensi Berwirausaha Pada Mahasiswa Program S1, 1(1), 1-13. https://doi.org/10.13140/ RG.2.2.12034.17602

Astuti, R.D., \& Martdianty, F. (2012). Students' Perception and Intention toward Entrepreneurship: Development of Planned Behaviour Entrepreneurial Model on Six State Universities in Indonesia. 2nd Annual International Conference on Enterprise Marketing and Globalization (EMG 2012).

Bae, T. J., Qian, S., Miao, C., \& Fiet, J. O. (2014). The Relationship Between Entrepreneurship Education and Entrepreneurial Intentions: A Meta-Analytic Review. Entrepreneurship: Theory and Practice, 38(2), 217-254. https://doi.org/10.1111/ etap. 12095

Bandura, A. (1997). Self-efficacy: toward a unifying theory of behavioural change. Psychological Review, 84, 191-215. 7.

The Influence of Attitude, Subjective Norms, Perception of Self-Control And Entrepreneurship Education on Entrepreneurial Intentions. 
Baron, R. A. (2004). The cognitive perspective: a valuable tool for answering entrepreneurship's basic —whyll questions. Journal of Business Venturing, 19(2), 221239.

Beritasatu.com. (2018). Indonesia Berpotensi Jadi Negara Maju. http:// www.beritasatu.com/ekonomi/224807-pakar-dari-as-indonesia berpotensijadinegara-maju.html (diakses Juli 10, 2018)

Bird, B. (1988). Implementing entrepreneurial ideas: the case for intention. Academy of Management Review 13(3), 442-453.

Bolton, D. L., \& Lane, M. D. (2012). Individual entrepreneurial orientation: Development of a measurement instrument. Education \& Training, 54, 219-233.

Cruz, L.D., Suprapti, S., Yasa, K. (2015). Aplikasi Theory Of Planned Behavior Dalam Membangkitkan Niat Berwirausaha Bagi Mahasiswa Fakultas Ekonomi Unpaz, Dili Timor Leste. E-Jurnal Ekonomi dan Bisnis Universitas Udayana. Vol. 4 No. 12 , pp. 895-920.

Engle, R.L., Dimitriadi, N., Gavidia, J.V., Schlaegel, C., Delanoe, S., Alvarado, I., He, X., Buame, S., \& Wolff, B. (2010). Entrepreneurial intent a twelve country evaluation of Ajzen's model of planned behaviour. International Journal of Entrepreneurial Behaviour \& Research, 16(1), 35-57.

Fretschner, M. \& Weber, S. (2013). Measuring and Understanding the Effects of Entrepreneurial Awarness Education. Journal of Small Business Management 51 (3): 410-428.

Gerba. D. T. (2012). Impact of entrepreneurship education on entrepreneurial intentions of business and engineering students in Ethiopia.African Journal of Economic and Management Studies.Vol. 3 No. 2.pp. 258-277.

Ghufron, M.N., dan Risnawita, S. (2009). Teori-Teori Psikologi. Jakarta: Gramedia

Iakovleva, T., Kolvereid, L., \& Stephan, U. (2011). Entrepreneurial intentions in developing and developed countries. Education \& Training, 53(5), 353-370. http:// dx.doi.org/10.1108/00400911111147686

Kurniawan, R. (2013). Pengaruh Penerapan Model Pembelajaran Teaching Factory Langkah (TF-6M) dan Prestasi Belajar kewirausahaan Terhadap Minat Wirausaha.Jurnal Pendidikan Teknologi Kejuruan.Vol. 10 No. 1.pp. 57-66.

Kautonen, T., Gelderen., M. V. \& Fink, M. (2015). Robustness of theory of planned behavior in predicting entrepreneurial intentions and actions. Entrepreneurship Theory \& Practice, 39(3), 655-674.

Liñán, F. (2008). Skill and value perceptions: how do they affect entrepreneurial intentions? International Entrepreneurship and Management Journal, 4(3), 257-272.

Liñán, F. \& Chen, Y. W. (2009). Development and cross-cultural application of a specific instrument to measure entrepreneurial intentions. Entrepreneurship Theory and Practice, 33(3), 593-617.

Liñán, F., Rodríguez-Cohard, J. C. \& Rueda-Cantuche, J. M. (2011). Factors affecting entrepreneurial intention levels: a role for education. International Entrepreneurship Journal, 7, 195218.

Liñán, F., Nabi, G. \& Krueger, N. (2013). British and Spanish entrepreneurial intention: A comparative study. Revista de Economía Mundial, 33, 73-103.

Leeuw, A. D., Valois, P., Ajzen, I., dan Schmidt, P. (2015). Using The Theory Of Planned Behavior To Identify Key Beliefs Underlying Pro-Environmental Behavior In HighSchool Students: Implications For Educational Interventions. Journal of Environmental Psychology. Vol. 42. pp. 128-138.

Luthans, F. (2008). Perilaku Organisasi. Jogjakarta: Andi.

Mahmoud, M. A., \& Muharam, F. M. (2014). Factors Affecting the Entrepreneurial

The Influence of Attitude, Subjective Norms, Perception of Self-Control And Entrepreneurship Education on Entrepreneurial Intentions. 
Intention of PhD Candidates: A study of Nigerian International Students of UUM. European Journal of Business and Management, 6(36), 17-24.

Marketing Research Indonesia. Wirausaha Indonesia Tertinggal Jauh. Diakses pada (2016, Februari) dari http://www.mri-research-ind.com/berita-249-wirausahaindonesiatertinggal-jauh.html

Nur. Ramadhani (2014). Pengaruh Sikap, Motivasi Intrinsik dan Self-Efficacy dengan Niat Wirausaha. Jurnal Psikologi Pendidikan. Vol. 3 No. 5

Purwanto. (2012). Metodologi Penelitian Kuantitatif Untuk Psikologi dan Pendidikan.Yogyakarta: Pustaka Pelajar.

Rahmi, E. R., Yusuf, M., dan Priyatama, A. N. (2014).Hubungan antara Motivasi Intrinsik dan Self-Efficacy dengan Keterlibatan Kerja pada Karyawan Bagian Konveksi PT Dan Liris Sukoharjo.Jurnal Ilmiah Psikologi Candrajiwa. Vol. 2No. 5

Rasli. M, Nurseto, T., Maulana (2014). Pendidikan Berbasis Entrepreneur. Jurnal Pendidikan Akuntansi Indonesia.Vol. 8 No. 2.

Rucker, D. D., Preacher, K. J., Tormala, Z. L., \& Petty, R. E. (2011). Social and Personality Psychology Compass, 5(6), 359-371.

Sukmaningrum \& Rahardjo. (2017). Faktor-Faktor Yang Mempengaruhi Niat Berwirausaha Mahasiswa Menggunakan Theory Of Planned Behavior (Studi pada Mahasiswa Pelaku Wirausaha Fakultas Ekonomika) Undergraduate thesis, Fakultas Ekonomika dan Bisnis.

Widawati, A.S. (2012). Faktor-Faktor Yang Mempengaruhi Niat Mahasiswa Untuk Berwirausaha: Aplikasi Theory Of Planned Behavior. Sinergi, Vol. 13 No. 1, pp. 92100 